\author{
Ks. Augustyn ECKMANN \\ (Lublin, KUL)
}

\title{
KONCEPCJA SZTUKI W PISMACH ŚWIĘTEGO AUGUSTYNA
}

W Katechizmie Kościoła Katolickiego (nr 32) czytamy: „biorąc za punkt wyjścia ruch i stawanie się, przygodność, porządek i piękno świata, można poznać Boga jako początek i cel wszechświata"1. Święty Paweł, którego dwu tysiąclecie urodzin obchodzimy, stwierdza w odniesieniu do pogan: „To bowiem, co o Bogu można poznać, jawne jest wśród nich, gdyż Bóg im to ujawnił. Albowiem od stworzenia świata niewidzialne Jego przymioty - wiekuista Jego potęga oraz bóstwo - stają się widzialne dla umysłu przez Jego dzieła" (Rz 1, 19-20)². Około 350 lat później św. Augustyn († 430) nauczał:

\begin{abstract}
„Zapytaj piękno ziemi, zapytaj morza, zapytaj powietrza, które rozprzestrzenia się i rozprasza; zapytaj piękno nieba, zapytaj porządek gwiazd, zapytaj słońce dzień swym blaskiem rozświetlające, zapytaj księżyc łagodzący blaskiem ciemności nocy bezpośrednio następującej, zapytaj zwierzęta [...] zapytaj wszystko, co istnieje. Wszystko ci odpowie: Spójrz i zauważ, jakie to piękne. Piękno tego, co istnieje, jest jego wyznaniem (confessio). Kto uczynił całe to piękno poddane zmianom, jeśli nie Piękny (pulcher), nie podlegający żadnej zmianie?"3.
\end{abstract}

\section{PIEKNO SZTUKI}

Święty Augustyn był tak od młodości wrażliwy na rzeczy piękne, że zaledwie ukończywszy studia, napisał rozprawę o sztuce z zakresu estetyki

${ }^{1}$ Katechizm Kościoła Katolickiego 32, Poznań 1994, 23.

2 Por. też Dz 14, 15 i 17; 17, 27-28; Mdr 13, 1-9. List do Rzymian został napisany w Koryncie pod koniec trzeciej podróży misyjnej św. Pawła (r. 58-60).

3 Sermo 241, 2, NBA 32/2, 640: ,interroga pulchritudinem terrae, interroga pulchritudinem maris, interroga pulchritudinem dilatati et diffusi aeris, interroga pulchritudinem caeli, interroga ordinem siderum, interroga solem fulgore suo diem clarificantem, interroga lunam splendore subsequentis noctis tenebras temperantem, interroga animalia...: interroga ista, respondent tibi omnia: ecce vide, pulchra sumus. Pulchritudo eorum, confessio eorum. Ista pulchra mutabilia quis fecit, nisi incommutabilis pulcher". Mowę tę wygłosił Biskup Hippony w V tygodniu po Wielkanocy ok. 405-410 r. (tak twierdząBeuron, Kunzelmann, Pontet), lub po 409 r. (Lambodt). 
De pulchro et apto, ale traktat ten się nie zachował. W Confessiones wyznaje:

„,kochałem piękność niższego rzędu, pogrążając się w przepaść. Mówiłem do przyjaciół: «Czyż kochamy cokolwiek innego oprócz piękności? I co to właściwie jest piękność? Co nas przyciąga i przywiązuje do rzeczy, które kochamy? Gdyby nie było w nich piękna i uroku, na pewno by nas nie nęciły». Gdy się przyglądałem rzeczom materialnym, uderzała mnie róźnica między pięknością przedmiotu, który się ujmuje jako odrębna całość, a pięknością, którą można dostrzec we właściwej proporcji między rzeczami; tak na przykład piękna może być proporcja między poszczególnymi członkami a całym ciałem albo obuwie może być dobrze dostosowane do stopy. Idea ta tak mocno utkwiła w moim umyśle, jak też w samej głębi serca, że napisałem książkę O pięknie i proporcji w dwóch czy trzech tomach. Nie pamiętam już - ale Ty wiesz to, Panie. Nie mam już tego dzieła, gdzieś mi się zagubiło".

Należy ubolewać, że te księgi zaginęły. Z pewnością znaleźlibyśmy w nich estetykę świętego Augustyna. Na szczęście nie jest to nie do naprawienia. Idee, dzięki Bogu, nie giną z taką samą łatwością, jak księgi. Święty Augustyn zachował w pamięci swoje myśli i chociaż ich nie usystematyzował, to jednak włączył je, być może te najważniejsze, do dzieła De vera religione. Pewne myśli i teorie na ten temat są też rozproszone w De ordine, De musica, w De doctrina christiana, a także w innych jego dziełach ${ }^{5}$.

Zauważmy najpierw, że jego nawrócenie nie pozbawiło go upodobania do rzeczy pięknych. Chociaż opłakiwał w Wyznaniach swoją przeszłość i odrzucał przywiązanie do rzeczy stworzonych, w nich właśnie znajdujemy przyznanie się, że pozostaje wciąż bardzo wrażliwy na przyjemności słuchu i wzroku:

„Przyjemności uszu mocniej mnie oplątały i ujarzmiły. Aleś mnie rozpętał i wyzwolił. Przyznaję, że i teraz w jakiejś mierze ulegam słodyczy kunsztownego śpiewu, któremu nadają życie wersety będące Twymi słowami, lecz nie aż tak się poddaję, bym nie był zdolny oderwać i odejść, gdy zechcę [...]. Kiedy jednak przypominam sobie łzy, jakie wylewałem słuchając śpiewów Twego Kościoła w pierwszym okresie po odzyskaniu przeze mnie wiary - a teraz wzruszam się już nie śpiewem, lecz rzeczami, o których się śpiewa, gdy czystym głosem są śpiewane na najbardziej odpowiednią melodię - znowu przyznaje temu obyczajowi wielką pożyteczność [...]. Coraz bardziej jednak skłaniam się do pochwalenia tego obyczaju, ze śpiewa się w kościele, aby poprzez przyjemność uszu mogła słabsza dusza wznosić się do stanu pobożności ${ }^{6}[\ldots]$. Pozostają jeszcze przyjemności oczu [...]. Oczy lubują się w pięknych różnorakich kształtach, w świetlistych

${ }^{4}$ Confessiones IV 13, 20, NBA 1, 100, thum. Z. Kubiak: Św. Augustyn, Wyznania 1987, Warszawa 1987, 76-77.

${ }^{5}$ Por. W. Tatarkiewicz, Estetyka św. Augustyna, w: tenże, Estetyka średniowiecza, II, Wrocław - Warszawa - Kraków 1962², 59-80.

${ }^{6}$ Confessiones X 33, 49-50, NBA 1, 342, 344, Kubiak, s. 254-255. 
i powabnych barwach [...]. Są one przed moimi oczyma przez całe dnie, nie mam chwili wolnej od ich naporu, jak nieraz mogę od wszystkich ochłonąć głosów, kiedy zapadną w milczenie. Sama bowiem królowa barw, jasność dzienna, nasycając sobą wszystko, co dostrzegamy - zawsze, gdziekolwiek za dnia się znajdę, przymila się do mnie coraz to innym układem swych promieni nawet wtedy, gdy zajęty czymś innym nie zwracam na nią uwagi. Tak przemożnie mną owłada, że jeśli nagle jej zabraknie, pragnę, aby powróciła; a jeśli długo jej nie ma, ogarnia mnie smutek"?.

Augustyn oskarża się ze swej „słabości”, że umiłował piękno, ale ta słabość nie wydaje mu się pełna winy, ponieważ przyznaje, że lubował się w tym pięknie i oświadcza, że był bezsilny, gdy chodzi o wyleczenie się z niego. Sztuka może mieć pewne niebezpieczeństwa, ale nie jest zła sama w sobie. Można więc przywiązać się do niej bez wielkich skrupułów i bez wielkich wyrzutów sumienia. Nie inaczej poucza Biskup Hippony swoich kleryków. Z pewnością chce ich odwieść od nadmiernego upodobania w dziełach sztuki. Nawet jej studiowanie jest nieużyteczne dla młodego człowieka. Liczne jednak ograniczenia, jakie towarzyszą temu wyrokowi, wskazują, że w rzeczywistości widzi on potrzebę uzupełnienia wychowania religijnego pojęciami estetycznymi. W De doctrina christiana pisze:

„Natomiast to, co dla ludzi jest wygodne i pożyteczne, czyli wszystko co odnosi się do ubrania, troski o ciało, podkreślenia właściwości płci oraz wyróżnienia ze względu na godności, jak też owe niezliczone rodzaje odznak, bez których społeczność ludzka nie mogłaby w ogóle - albo też nie tak korzystnie i sprawnie funkcjonować, zostało z pożytkiem ustanowione przez ludzi dla ludzi ${ }^{8}[\ldots]$. Otóż tej całej dziedziny ludzkich intuicji koniecznych do prowadzenia życia chrześcijanin żadną miarą nie powinien unikać, lecz przeciwnie, w miarę potrzeby poznawać ją i o niej pamiętać",.

To zainteresowanie będzie istniało zawsze, zwłaszcza gdy chodzi o wielkie dzieła. Augustyn zastanawia się, skąd pochodzi to instynktowne uczucie, które nas skłania do miłowania rzeczy pięknych, do odczuwania subtelnych i rzadkich radości w tym zamiłowaniu. W Confessiones pyta, czym jest piękno, a ponieważ sztuka piękno odtwarza albo je stwarza, wobec tego, czym jest sama sztuka. Zdaniem Uczonego z Tagasty, najpewniejszym środkiem dowiedzenia się tego jest badanie estetycznej natury przyjemności. Zauważa najpierw, że ta przyjemność, która składa się z wielu składników i której wrażliwość i wyobraźnia odgrywają wielką rolę, jest ze swej istoty porządku racjonalnego. W De ordine pisze:

7 Tamze X 34, NBA 1, 330, Kubiak, s. 255-256.

${ }^{8}$ De doctrina christiana II 25, 39, NBA 8, 108, tłum. J. Sulowski, PSP 22, 59, lub Patres Ecclesiae, vol. 1, Warszawa 1989, 93.

9 De doctrina christiana II 26, 40, PSP 22, 59, Patres Ecclesiae, vol. 1, s. 93. 
„Jeśli chodzi o przedmiot podpadający pod wzrok, w którym harmonia poszczególnych części jest, jak to się mówi, rozumowa, to taki przedmiot nazywamy zazwyczaj pięknym"10.

\section{Myśl tę kontynuuje w De vera religione:}

„Człowieka jednak, który w głąb patrzy i dostrzega niewidzialne, będę w dalszym ciągu nagabywał, dlaczego nam się coś podoba; niech okaże się sędzią ludzkich przyjemności. W ten sposób wzniesie się ponad nią i nie da się przez nią opanować, kiedy będzie sądził nie według niej, lecz o niej samej. Przede wszystkim zapytam, czy dlatego coś jest piękne, że się podoba, czy też dlatego się podoba, że jest piękne. Bez wątpienia otrzymam odpowiedź, że dlatego podoba się, ponieważ jest piękne. Zapytam więc z kolei, dlaczego jest piękne; a jeśli on zacznie się wahać, podpowiem, czy przypadkiem nie dlatego, że części danej rzeczy są do siebie podobne i przez pewien wzajemny związek osiągają zgodność i jedność"11.

Wraca do tego problemu w De ordine:

„Odkryliśmy, o ile pozwalają na to nasze dociekania, pewne ślady rozumu w zmysłach, jeśli zaś chodzi o to, co dotyczy wzroku i słuchu, to nawet w samych doznaniach przyjemności...Uznać więc wypada, w zakresie przyjemności, jakich dostarczają nam te zmysły, to tylko ma związek z rozumem, co odznacza się pewną miarą i proporcją (id ad rationem pertinere fateamur, ubi quaedam dimensio est atque modulatio)" 12 .

Augustyn daje różne przykłady. Powołuje się na architektów, którzy w poszczególnych częściach budynku rozmieszczonych proporcjonalnie, dostrzegają element rozumowy. To samo zjawisko pojawia się prawie we wszystkich sztukach i dziełach ludzkich. Aby jakieś dzieło było piękne, trzeba przede wszystkim, by rozum w nim się odnalazł, by radował się widząc, że tam są zachowane jego prawa, bo on ożywia dzieło oraz je porządkuje. Rola rozumu nie zatrzymuje się jednak na wprowadzaniu porządku we wszystkie składniki poematu czy obrazu i rozkładania ich według doskonałych proporcji. Trzeba jeszcze, aby te proporcje były harmonijnie rozmieszczone. Autor nasz pisze:

„We wszystkich umiejętnościach ceni się zgodność, która jest podstawą trwałości i piękna we wszystkim ${ }^{13}[\ldots]$. Takie zresztą poczucie zgodności jest bliższe rozumu i prawdy. Bez wątpienia jednak zastanowimy się nad tym, dlaczego nas razi, jeśli z dwóch okien, umieszczonych nie jedno nad drugim, lecz obok siebie, jedno jest większe lub mniejsze, choć mogłyby być równe? Jeśli zaś umieścimy je jedno nad

${ }^{10}$ De ordine II 11, 33, NBA 3, 330, tłum. J. Modrzejewski: O porzq̨dku, w: Św. Augustyn, Dialogi filozoficzne, I, Warszawa 1953, 209.

${ }_{11}$ De vera religione 32, 59, NBA 6/1, 94, tłum. J. Ptaszyński: O wierze prawdziwej, w: Św. Augustyn, Dialogi filozoficzne, IV, Warszawa 1954, 122.

12 De ordine II 11, 33, NBA 3, 330-332, Modrzejewski, s. 209.

13 De vera religione 30, 55, NBA 6/1, 88, Ptaszyński, s. 118. 
drugim, już ta nierówność nie będzie nas tak raziła, choćby jedno było o połowę mniejsze od drugiego" 14 .

\section{W De musica zastanawia się nad ruchem czasowym i liczbami:}

„Co jest przyczyną upodobania, jakie znajdujemy w liczbach zmysłowych? Cóż innego, jeśli nie pewnego rodzaju równomierność i równo odmierzone odstępy? Czyż stopa pyrrychiczna lub spondaiczna, anapestyczna lub daktyliczna, proceleuzmatyczna czy dyspondaiczna mogłaby nas cieszyć, gdyby jedna ich część nie odpowiadała drugiej dzięki równomierności podziału? A na czym polega piękność jambu, trocheja i trybrachu, jeśli nie na tym, że mniejsza część stopy może podzielić większą na dwie równe części? Dlaczego następnie stopy sześciomorowe brzmią milej i uroczyściej?"15.

Przyjemność wzroku i przyjemność słuchu są więc związane z dwoma elementami rozumowymi: proporcją i harmonią. Harmonia (convenientia) wprowadza w różne już uporządkowane części dzieła sztuki stosunek pewnej odpowiedniości i solidarności. Rozdziela je zależnie od ich znaczenia, grupuje je według ich powinowactwa, łączy artystycznie według ich barwy i tonu. To połączenie w harmonijny, zgodny układ nadaje odcieniom dźwięku i kadencjom rytmu wartość ekspresji wyrażonej we współgrze światła i cieni, symetrii linii i wypukłości rysunku. To jeszcze jednak nie wystarcza do pełnego piękna.

Harmonia (convenientia - zgodność) wymaga równości (aequalitas) ${ }^{16}$. Ona nie może wywierać wpływu na nasze zmysły, a przez zmysły na nasz rozum, jeśli te elementy, które wprowadza w nie, są w swoim rodzaju jednakowo doskonałe. $\mathrm{Z}$ chwilą, gdy jeden $\mathrm{z}$ nich detonuje instrument $\mathrm{w}$ czasie koncertu, strofę w poemacie, barwę w obrazie, całość dzieła jest zepsuta przez jego niedoskonałość. Nie ma już ani harmonii, ani piękna. Ta równość w doskonałości ma swe źródło w głębszej równości, której prawo jest podstawą wszelkich umiejętności i wszystkich sztuk. Nauki mają za przedmiot ustalenie stałych stosunków istniejących między rzeczami i one wyrażają te stosunki w równaniach. Biskup następująco wyjaśnia to w De vera religione:

„Skoro więc według ogólnej zasady czworokątności sądzimy, że czworokątne są i rynek, i kamień, i tabliczka, i klejnot, a według ogólnej zasady równości (aequalitatis legem) sądzimy o równomierności ruchów biegnącej mrówki i kroczącego słonia, któż może wątpić, że owa zasada nie jest ani większa, ani mniejsza od żadnego odcinka w czasie i przestrzeni, natomiast ważnością przewyższa wszystko!"17 [...]. Otóż te rzeczy piękne podobają nam się dzięki zawartej w nich liczbie, której celem [...] jest równość. Zjawisko to bowiem odkrywamy nie tylko w pięknie

14 Tamże 30, 54, NBA 6/1, 87-88, Ptaszyński, s. 118.

15 De musica VI 10, 26, NBA 3/2, 664, tłum D. Turkowska: O muzyce, w: Św. Augustyn, Dialogi filozoficzne, IV, Warszawa 1954, 46.

16 Por. De vera religione 30, 55, NBA 6/1, 88, Ptaszyński, s. 118.

17 Tamże 30, 56, NBA 6/1, 90, Ptaszyński, s. 120. 
zjawisk słuchowych i ruchów ciał, ale nawet w kształtach widzialnych, do których bodajże częściej odnosimy nazwę piękności [...]. A weźmy nawet światło widzialne, któremu przysługuje pierwszeństwo wśród wszystkich barw - bo w wyglądzie ciał cieszy nas także barwa. Czyż w świetle i barwach nie poszukujemy tego, co odpowiada naszemu oku? Odwracamy się od zbyt silnego blasku i niechętnie patrzymy na rzeczy mało widoczne, podobnie jak spośród dźwięków odrzucamy zbyt głośne, a nie lubimy także głosów przypominających szepty [...]. A podobnie jak mrok jest przeciwieństwem kolorów, tak milczenie jest negacją dźwięku. W tej dziedzinie poszukujemy zjawisk harmonizujących z naszą naturą, a odrzucamy wszystko, co z nią niezgodne, a co jednak - jak widzimy - odpowiada innym stworzeniom. Czyż nie cieszy nas pewne prawo równości? [...]. Nie ma bowiem rzeczy zmysłowych, w których nie cieszyłaby nas równość lub podobieństwo [...]. Nic nie jest przecież tak równe i podobne jak jeden i jeden" 18 .

A zatem, ażeby jakieś dzieło nam się podobało, potrzeba, by „odpowiadało naszej naturze” i ,było zgodne z naszym rozumem”. Rozum z kolei znajduje rozkosz w stosunkach zgodności i równości. Poszukuje ich w przyrodzie, ujmuje je własnymi pojęciami, a jego szczęście polega na odnajdywaniu ich w przedmiotach, które przedstawia się nam do podziwiania. W De vera religione czytamy:

„Mogę bowiem powiedzieć, dlaczego podobne sobie człony jakiegokolwiek ciała winny się znajdować po obu stronach naprzeciwko siebie: ponieważ zachwycam się najwyższą równością, którą ogarniam nie oczyma ciała, lecz myśli. Dlatego sądzę, że to, co spostrzegam oczyma, tym jest lepsze, im bardziej według swej istoty zbliża się do tego, co pojmuje duchem. Dlaczego zaś tak jest, tego nikt nie może powiedzieć. Nikt rozsądny nie powie nawet, że tak powinno być - jak gdyby mogło być inaczej"19

To prawo umysłu, które wszystkim elementom dzieła sztuki narzuca proporcje nie tylko słuszne i harmonijne, ale także równe i symetryczne jest oczywiście tajemnicą ${ }^{20}$. Głosi to sama przyroda, a nasz rozum podpisuje się pod tym. Abyśmy jednak dostrzegali te piękna przyrody, jak i piękna artystyczne, muszą one odpowiadać naszemu rozumowi. Nasz rozum z kolei, chcąc uchwycić głębię wszystkich rzeczy, musi je sprowadzić do stosunków równości (aequalitas). Równość proporcji jest jednym z warunków sztuki. Sztuka wymaga jeszcze czegoś więcej, a mianowicie jedności (unitas), która stanowi jej doskonałość i ukoronowanie:

„We wszystkich umiejętnościach (in omnibus artibus) ceni się zgodność (convenientia), która jest podstawą trwałości i piękna we wszystkim. Zgodność zaś sama dąży do równości i jedności (ad aequalitatem unitatemque) już to przez podobieństwo równych części, już to przez stopniowanie nierównych"21.

18 De musica VI 13, 38, NBA 3/2, 680, 682, Turkowska, s. 56-57.

19 De vera religione 31, 57, NBA 6/1, 90, Ptaszyński, s. 120.

${ }^{20}$ Por. tamże 30, 55, NBA 6/1, 88, Ptaszyński, s. 118-119.

21 Tamże. 
W tym sztuka jest podobna do wiedzy, która z równości składnie ułożonych części usiłuje odkrywać jedyną formułę wyjaśniającą wszechświat. Nie ma nic bardziej słusznego, niż jej wymagania. Niestety, nic nie ma też bardziej daremnego. Jest oczywiste, że piękno obrazu, posągu lub poematu, nie zależy wyłącznie od doskonałości szczegółów i harmonijnego doboru części, ale także od czegoś, co jest ukryte, i co wiąże wszystkie składniki z jakąś głęboką ideą, która je jednoczy twórczym tchnieniem dającym im duszę.

„Wszyscy więc według swych zadań i celów mają swe wyznaczone miejsce w pięknie wszechświata i dlatego nawet to, co w oderwaniu przeraża nas, zupełnie nas zadowoli, jeśli to będziemy rozpatrywać na tle całości. Przecież nie możemy oceniać budowli jedynie na podstawie jednego kąta, urody człowieka tylko na podstawie włosów, dobrego mówcy tylko na podstawie ruchu rąk, a obrotu księżyca na podstawie oglądanych przez trzy dni niektórych jego postaci”22.

„Z czego czerpiemy tu przyjemność, jeśli nie z porządku? Razi nas przecież wszystko, w czym początek nie wiąze się harmonijnie ze środkiem, a środek z końcem" ${ }^{23}$.

Jedność jest tak bardzo duszą piękna, że dzieła przyrody i człowieka wydają się nam brzydkie, kiedy ich części tracą spoistość i zaczynają się rozkładać. Augustyn wyjaśnia:

„Liczby rozpoczynają się od jedności, równość i symetria czyni je pięknymi, porządek zaś - jednolitymi. Każdy więc musi przyznać, że wszelkie stworzenie, aby osiągnąć swą właściwą naturę, dąży do jedności, stara się w miarę sił utrzymać podobieństwo gatunku i zajmować właściwe miejsce czy to w czasie, czy w przestrzeni, w ciele zaś utrzymywać zdrowie przez swego rodzaju równowagę ${ }^{24}$.

Koniec tej równowagi i stałości to zepsucie i śmierće ${ }^{25}$.

\section{SZTUKA LUDZKA}

To, co jest prawdziwe dla istot żyjących, rzeczywistych arcydzieł przyrody, jest także prawdziwe, gdy chodzi o piękno, które stwarza człowiek swym umysłem albo rękami. Dzieła te mogą żyć i stawać się nieśmiertelne tylko wtedy, kiedy wszystkie ich składniki zlewają się w jakąś jedność harmonijną, stają się w ten sposób nierozdzielne i nie poddają się rozkładowi.

Człowiek ma rozum (ratio), dzięki któremu poznaje idee i liczby i przez ciągłe nowe kombinacje może wymyślić nowe dzieła sztuki ${ }^{26}$, napotykając

22 Tamże 40, 76, NBA 6/1, 114, Ptaszyński, s. 134.

23 De musica VI 14, 47, NBA 3/2, 692, Turkowska, s. 63.

${ }^{24}$ De musica VI 17, 56, NBA 3/2, 700: „Numeus autem et ab uno incipit”, Turkowska, s. 68.

25 Por. De vera religione 20, 38, NBA 6/1, 64, Ptaszyński, s. 105.

26 Por. tamże 80, NBA 6/1, 120, Ptaszyński, s. 137-138. 
wszędzie ślady Bożej mądrości ${ }^{27}$, podczas gdy jaskółka na jeden sposób lepi gniazdo. Wprawdzie w gniazdach jaskółek znajdują się także liczby i proporcje, ale jaskółki budują „operante natura”. Ludzka „,ars” przewyższa twórczość jaskółek nie „numerosa faciendo”, lecz „,numerosos cognoscendo"28; toteż Augustyn rozgranicza technikę zwierząt od ludzkiej sztuki. Wyższość człowieka w stosunku do zwierząt i jego zwierzchność nad nimi polega na tym, że wie co czyni, bo jest stworzeniem rozumnym. „Ars” ludzką określa jako zdolność do wydawania samodzielnego sądu. Autor nasz wyraźnie odróżnia „ars” związaną z teorią (ratiocinando) od opierającej się na doświadczeniu ,,ars vulgaris”, która ma do czynienie z „usus”:

„Musimy zbadać istotę samej sztuki. Mam na myśli nie tę sztukę, umiejętność lub naukę, która gromadzi doświadczenie, lecz tę, która rozumem docieka [...] jak widać pospolita umiejętność polega jedynie na zapamiętaniu udanych doświadczeń w połączeniu z pewną wprawą w wykonywaniu pracy"29.

Pojęciowe zróżnicowanie między „,ars”, „disciplina” i „,sapientia” nie jest wyraźnie określone. Uczony Afrykańczyk pisze, że życie rozumne jest o tyle lepsze, o ile dokładniej opanuje jakąś sztukę, umiejętność lub mądrośćc ${ }^{30}$. Człowiek napotyka ślady mądrości Bożej w pięknie zewnętrznym. W ten sposób Bóg pociąga człowieka do jego własnego wnętrza, gdzie odkryje zasady piękna. „Ars” ma swe źródło w nieśmiertelnej duszy ludzkiej, w której artysta obecne liczby i idee odtworzone stawia naprzeciwko przemijalnego dzieła ${ }^{31}$. W Komentarzu do Ewangelii św. Jana Biskup Hippony pisze:

„Faber facit arcam. Primo in arte habet arcam: si enim in arte arcam non haberet, unde illam fabricando proferret? Sed arca sic est in arte, ut non ipsa arca sit, quae videtur oculis. In arte invisibiliter est, in opere visibiliter erit. Ecce facta est in opere; numquid destitit esse in arte? Et illa in opere facta est, et illa manet quae in arte est: nam potest illa arca putrescere, et iterum ex illa quae in arte est, alia fabricari. Adtendite ergo arcam in arte, et arcam in opere. Arca in opere non est vita, arca in arte vita est; quia vivit anima artificis, ubi sunt ista omnia antequam proferantur" ${ }^{\prime 32}$.

${ }^{27}$ Por. De libero arbitrio II 42, NBA 3/2, 284, tłum. A. Trombala: $O$ wolnej woli, w: Św. Augustyn, Dialogi filozoficzne, III, Warszawa 1953, 153-154.

28 Por. De ordine II 19, 49, NBA 3, 352, Modrzejewski, s. 222.

${ }^{29}$ De vera religione $30,54, \mathrm{NBA} 6 / 1,86-88$ : ,ipsius artis natura quaerenda est. Neque nunc artem intellegi volo, quae notatur experiendo, sed quae ratiocinando indagatur [...]. Ita reperitur nihl esse aliud artem vulgarem, nisi rerum expertarum placitarumque memoriam, usu quodam corporis atque operationis adiuncto", Ptaszyński, s. 118

${ }^{30}$ Por. tamże 30, 54, NBA 6/1, 86: ,rationalis vita [...] tanto autem melius iudicat, quanto est peritior; tanto est peritior, quanto alicuius artis vel disciplinae vel sapientiae particeps est".

31 Por. De libero arbitrio II 42; NBA 3/2, 264-267; Confessiones I 6, 7, NBA 1, 8-11.

32 In Iohannis Evangelium tractatus 1, 17, NBA 24/1, 20, tłum. własne: „Rzemieślnik robi skrzynię. Najpierw ma tę skrzynię w umyśle. Gdyby bowiem nie miał jej idei skonstruowania 
„Ars humana” jest przez Boga stworzona, stanowi część Bożego stworzenia. Bóg pozwolił duchowi człowieka przez siebie stworzonemu nauczyć się różnych umiejętności: ,etiam scientias artium variarum”33. „Ars humana” została dana jako naśladowanie, odwzorowanie idei - imitatio $^{34}$ i wsparcie natury:
„Ars illa summa omnipotentis Dei, per quam ex nihilo facta sunt omnia, quae etiam sapientia eius dicitur, ipsa operatur etiam per artifices, ut pulchra et con- gruentia faciant, quamvis non de nihilo, sed de aliqua materia operentur, velut ligno aut marmore aut ebore et si quod aliud materiae genus manibus artificis subditur" 35 .

W ten sposób Augustyn wyjaśnia starą myśl o naśladowaniu natury przez technikę w świetle nauki o stworzeniu. „Ars humana” staje się środkiem boskiej troski o świat, środkiem ,creatio continua”. Augustyn wyjaśnia to przy pomocy stoickiej nauki o ,rationes seminales”. Bóg stworzył wszystko jednocześnie przyczynowo i potencjalnie (omnia simul causaliter i potentialiter) ${ }^{36}$,

w umyśle, jakże mógłby ją wykonać. Naturalnie skrzynia, która jest w umyśle rzemieślnika nie jest dokładnie tą samą, którą widzimy naszymi oczyma. W myśli jest niewidzialna, kiedy zostanie zrobiona, będzie widzialna. Oto została wykonana; czy przestała istnieć w umyśle? Nie, idea została zrealizowana w dziele, ale pozostaje w umyśle twórcy. Skrzynia owa może zbutwieć i z idei, która jest w umyśle, inna może być zrobiona. Zastanówcie się więc nad tą skrzynią w umyśle i skrzynią wykonaną. Skrzynia zrobiona nie jest życiem, skrzynia istniejąca w umyśle jest życiem, ponieważ żyje dusza mistrza, w której są wszystkie rzeczy zanim zostaną wykonane"; zob. też tamże 37, 8; De Genesi contra manichaeos I 13, NBA 9/1, 76; De civitate Dei XI 29, NBA 5/2, 126; De doctrina christiana II 48, NBA 8, 116; In Epistolam Iohannis ad Parthos tractatus 8, 10, NBA 24/2, 1802-1805.

${ }^{33}$ De civitate Dei VII 30, NBA 5/1,522-524; por. też XIII 18, NBA 5/2, 252: „Si enim ars humana efficit, ut ex metallis, quae in aquis posita continuo submerguntur, quibusdam modis vasa fabricata etiam natare possint: quanto credibilius et efficacius occultus aliquis modus operationis Dei, cuius omnipotentissima voluntate Plato dicit nec orta interire nec conligata posse dissolvi, cum multo mirabilius incorporea corporeis quam quaecumque corpora quibuscumque corporibus copulentur, potest molibus praestare terrenis, ut nullo in ima pondere deprimantur, ipsis que animis perfectissime beatis, ut quamvis terrena, tamen incorruptibilia iam corpora ubi volunt ponant et quo volunt agant, situ motu que facillimo! An vero si hoc angeli faciant et quaelibet animalia terrestria rapiant unde libet constituantque ubi libet, aut eos non posse aut onera sentire credendum est?”; tamże 21, 6, NBA 5/3, 226: „Aut ergo in lucerna illa mechanicum aliquid de lapide asbesto ars humana molita est aut arte magica factum est, quod homines illo mirarentur in templo, aut daemon quispiam sub nomine Veneris tanta se efficacia praesentavit, ut hoc ibi prodigium et appareret hominibus et diutius permaneret".

${ }^{34}$ De doctrina christiana II 47, Patres Ecclesiae vol. 1, s. 98; De civitate Dei VII 30, NBA 5/1, $522-525$.

35 De diversis quaestionibus 83, 78, NBA 6/2, 234, tłum. własne: „Owa najwyższa stuka Boga Wszechmogącego, który wszystkie rzeczy stworzył z niczego, i która także jest nazywana mądrością, działa także za pośrednictwem artystów, aby tworzyli rzeczy piękne i harmonijne, chociaż nie z niczego, lecz z określonej materii, jak z drzewa, marmuru albo z kości słoniowej czy z jakiejkolwiek innego rodzaju materii dostępnego artyście".

${ }^{36}$ De Genesi ad Litteram contra manichaeos V 23, 45; VI 6, 11, NBA 9/2, 280-282 i 298; PSP 25, 214 i 219-220; por. tamże IV 33, 51; V 23, 44-46; IX 17, 32. 
zanim się rozwinęło, jak to jest znane w dziełach, które Bóg aż dotąd spełnia. Bóg stworzył świat w formie tkwiących nasion, idei i sił (rationales seminales), w których wszystko przyszłe zostało zawarte i Bóg stwarza aż dotąd, usque modo (J 5, 17), przez rozwój sił. Ta moc Stwórcy jest przyczyną istnienia wszelkiego stworzenia. Gdyby jej zabrakło, świat przestałby istnieć $^{37}$. Możliwości dane stworzeniu są z jednej strony siłami natury, z drugiej ludzkiego ducha, który artes wydobywa i nimi naturę naśladuje. Wewnątrz tego systemu boskiej providentia znajduje się moc ars, która może naśladować i wykorzystać w stworzeniu zawarte liczby, stosunki, prawa i w nich ukrytą dynamikę ${ }^{38}$. Przy tamtejszym stanie techniki najbardziej jest widoczna w najłatwiejszej sztuce $\operatorname{ars}_{\text {rolnika }}{ }^{39}$ i lekarza ${ }^{40}$. Tak też wyjaśnia Augustyn cudowne zjawiska. W De civitate Dei daje przykład nie dającej się zgasić lampy (lucerna inextinguibilis), w świątyni Wenus, tłumacząc, że jest to cudem techniki (artes humanae) albo działaniem demonów (artes magicae $)^{41}$, które wyjaśnia przez rationes seminales określone w dynamice stworzenia ${ }^{42}$. Władza demonów także pochodzi od Boga. Bóg jako pierwsza przyczyna kieruje działaniem przyczyn wtórnych. Augustyn porównuje demoniczne zdolności z zawodową znajomością lekarza, który wprawdzie artis ignarus, ale dzięki swej wiedzy może przewidzieć cielesny rozwój człowieka. To jego przewidywanie może budzić podziw i być uznane za cud $^{43}$. Właśnie w świetle tego przykładu Augustyn stara się ukazać w artes magicae wyraźnie ars jako daną przez Boga możliwość stworzeniu i podporządkowaną Stwórcy. Ars prowadzi do urzeczywistnienia tego, co Bóg dał stworzeniu jako możliwość. Późniejsza tendencja, by widzieć człowieka jako drugiego stwórcę nie wchodzi u Augustyna w rachubę. Biskup Hippony odrzuca pojęcie creare przy artes magicae $e^{44}$.

W swych wczesnych pismach Uczony z Tagasty zdaje się przyjmować starożytną tradycję warońsko - neopitagorejsko - neoplatońską jako źródło w programie wykształcenia artes liberales czy disciplinae liberales w programie éwiczenia ducha na drodze do prawdy ${ }^{45}$. Próba naśladowania Warrona

37 Por. tamze IV 12, 22-23, NBA 9/2, 182-185; PSP 25, 176-177.

38 Por. tamże VIII 9, 17, NBA 9/2, 410; De civitate Dei VII 30; XXII 24, NBA 5/1, 522-525; NBA 5/3, 390-397.

39 Por. De Trinitate III 8, 13-14, NBA 4, 144-149.

40 Por. De divinatione daemonum 5, 9, NBA 6/2, 658: „Neque enim quia praevidet medicus, quod non praevidet eius artis ignarus, ideo iam divinus habendus est".

41 Por. De civitate Dei XXI 6, NBA 5/3,226, por. tamże X 9 i 27; Confessiones VII 8; Epistolae 118,$33 ; 137,13 ; 138,18 ;$ De Trinitate III 16.

42 Por. De civitate Dei VIII 19, NBA 5/1, 584-587.

43 Por. De divinatione daemonum 5, 9, NBA 6/2, 658; zob. też tamże 5, 8, NBA 6/2, 456-458; De Trinitate III 12-15, NBA 4, 142-150.

44 Por. De Trinitate III 13, NBA 4, 144-147.

45 Por. Soliloquia I 13, 23, NBA 3, 464-467; De quantitate animae 25, NBA 3/2, 52. 
pod mottem: ,per corporalia ad incorporalia”, by dać wyczerpujące przedstawienie artes liberales (disciplinae liberales) osiągnęła cel tylko częściowo $^{46}$. W De ordine kreśli Augustyn drogę wykształcenia rzeczy stworzonych przez rozum: „ratio [...] peperit artem" 47 dla praktycznego pożytku poznania i zrozumienia rzeczywistości sztuk, których wewnętrzny związek jest dany przez liczby. Augustyn po wielu zastrzeżeniach opisuje cykl siedmiu artes liberales ${ }^{48}$. W De quantitate animae obrazuje siedem stopni rozwoju duszy i jako trzeci, właściwy człowiekowi uważa sztukę i wiedzę ${ }^{49}$. Wśród wielu innych artes wyliczając: uprawę pól, miejskie budowle, pomniki architektury i techniki, języki, literaturę, malarstwo, rzeźbę, podkreśla potęgę rozumowania i wynalazczości. Kończy zaś pozytywnym, ale ambiwalentnym stwierdzeniem:

„Magna haec et omnino humana. Sed est adhuc ista partim doctis atque indoctis, partim bonis ac malis animis copia communis" 50 .

W De doctrina Christiana podaje Augustyn pełnię tradycji wykształcenia w dużym programie. Nie chodzi jemu już tylko o podstawowe znaczenie artes dla wykształcenia i duchowych korzyści, lecz o wykorzystanie przekazanej wiedzy na użytek chrześcijan i dla studium Pisma Świętego. Doktor Kościoła daje przy tym biegłe rozróżnienie między artes liberales i sztukami rzemieślniczymi. Odróżnia on dwa główne typy doctrinae, a mianowicie artes wprowadzone przez ludzi (ipsis hominibus institutae), czyli opierające się na konwen$\mathrm{cji}^{51}$, oraz te, które bazują na tym, co ludzie w naturze albo w historii znajdą gotowe (transacta temporibus) ${ }^{52}$. Wśród tych pierwszych odróżnia on artes magicae zrobione z udziałem demonów, na przykład astrologia i urządzenia sporządzone przez ludzi dla ludzi, częściowo „superflua luxuriosaque”, jak

${ }^{46}$ Por. Retractationes I 6, NBA 2, 30-33, PSP 22, 194.

${ }^{47}$ De ordine II 13, 38, NBA 3, 338: „Illa igitur ratio perfecta dispositaque grammatica, admonita est quaerere atque attendere hanc ipsam vim, qua peperit artem: nam eam definiendo, distribuendo, colligendo, non solum digesserat atque ordinaverat, verum ab omni etiam falsitatis inreptione defenderat”, Modrzejewski s. 212: „Ułożywszy i uporządkowawszy gramatykę rozum skierował się znów ku szukaniu zasady dzięki której powstała owa sztuka; przy pomocy definicji analizy i syntezy nie tylko ustalił w tej dziedzinie pewien porządek, lecz również uchronił ją przed wśliznięciem się do niej wszelkiego rodzaju błędów".

${ }_{48}$ Por. De ordine II 16, 44, NBA 3, 344-347.

49 Por. De quantitate animae 33, 70 - 33, 76, NBA 3/2, 114-125.

50 Tamże 33, 72, NBA 3/2, 118, tłum D. Turkowska: O wielkości duszy, w: Św. Augustyn, Dialogi filozoficzne, II, Warszawa 1953, 182: „wszystko to są rzeczy wielkie i właściwe rodzajowi ludzkiemu. Lecz i to jeszcze stanowi wspólne dobro dusz z jednej strony wykształconych lub prostackich, z drugiej - dobrych lub złych"; por. paralelny, ale odmienny sąd Cycerona pod koniec podobnego biegu myśli w Tusculanae disputationes I 67: , haec magna, haec divina, haec sempiterna sunt".

51 Por. De doctrina christiana II 30-40, NBA 22, 114-132.

52 Tamze II 41-57, NBA 22, 108-126. 
widowisko teatralne, częściowo celowe i konieczne osiągnięcia kulturalne, jak ubrania, pismo i język ${ }^{53}$.

Co do wiedzy, którą ludzie wynaleźli, zalicza on z jednej strony disciplinae odnoszące się do zrozumienia: logikę i matematykę ${ }^{54}$, z drugiej strony cielesnozmysłowe doświadczenie odnoszące się do historii, przyrody, astronomii i pozostałych artes $^{55}$. Te pozostałe artes dzieli na trzy kolejne:

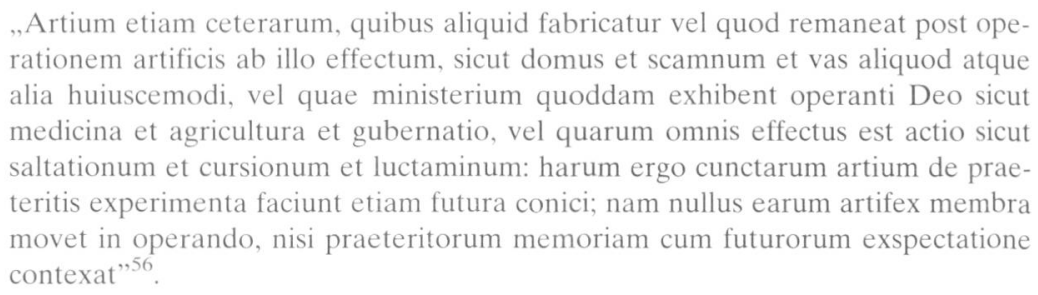

Doktor Kościoła widzi potrójne znaczenie artes liberales: intelektualne, w którym przede wszystkim chodzi o ćwiczenie ducha ${ }^{57}$, praktyczne dla potrzeb życia i poznania oraz kontemplacji rzeczywistości (partim ad usum vitae, partim ad cognitionem rerum contemplationemque $)^{58}$, ,, ad adiuvandam vitam naturamque "59, ,ad utilitatem proximi" ${ }^{\prime 60}$, wreszcie estetyczne, mające swe źródło w największym Pięknie ${ }^{61}$, któremu Biskup Hippony głosi hymn pochwalny i składa dziękczynienie.

Augustyn widzi też niebezpieczeństwa, jakie może wywołać sztuka. Wymienia niebezpieczeństwa natury praktyczno-moralnej, wywołane nadmiarem, przypominając powiedzenie Terencjusza: „Ne quid nimis”, zwłaszcza w sprawach ciała, w zależności od okoliczności czasu i miejsca ${ }^{62}$, oraz intelektualne

53 Por. tamze II 38, NBA 22, 106; De civitate Dei XXII 24, NBA 5/3, 390: ,,artes [...] partim necessariae, partim voluptariae".

${ }^{54}$ Por. De doctrina christiana II 48-57, NBA 22, 116.

55 Por. tamże II 42-47, NBA 22, 110-114.

56 Tamże II 30, 47, NBA 22, 114, Patres Ecclesiae, vol. 1, 99: „Znane są także inne sztuki, których celem jest wytwarzanie określonego gatunku przedmiotów. W jednym przedmiot taki powstaje jako skutek działania wytwarzającego go człowieka, na przykład stołek czy naczynie albo inny tego rodzaju wytwór. W innych działający służy jako narzędzie w boskim działaniu, tak na przykład w medycynie, rolnictwie czy w sztuce prowadzenia okrętów. W jeszcze innym cały skutek polega na działaniu, jak to ma miejsce w skokach, biegach czy zapasach. Otóż praktyka tych wszystkich sztuk ukazuje, że i tu w jakiś sposób wnioskuje się o przyszłości na podstawie doświadczenia przeszłości”; co do tego trójpodziału por. Seneca, Epistola 88, 21.

57 Por. Soliloquia 23, NBA 3, 464-467; De quantitate animae 25, NBA 3/2, 52.

58 Por. De ordine II 44, NBA 3, 346.

59 De civitate Dei VII 30, NBA 5/1, 524

${ }^{60}$ De musica VI 14, 45, NBA 3/2, 690; por. tez De civitate Dei XXII 44; Enarrationes in Ps. 83, 8.

61 Por. De civitate Dei 22, 24, NBA 5/3, 386-397; Confessiones X 53, NBA 1, 346.

${ }^{62}$ De doctrina christiana II 58, NBA 8, 128, Patres Ecclesiae, vol. 1, s. 110; por. też Confessiones X 53 . 
mieszczące się w curiositas, która może odwrócić uwagę od koncentracji na tym, co nieprzemijalne, nieśmiertelne ${ }^{63}$. Zarzut curiositas stawia Biskup Hippony przede wszystkim w związku z negatywną oceną artes magicae ${ }^{64}$; czyni też rzeczowe rozróżnienie między astronomią i astrologią ${ }^{65}$.

\section{SZTUKA BOSKA}

Boga, silniej niż w klasycznej literaturze antyku, nasz Ojciec Kościoła nazywa artifex, a jego dzieło stworzenia $\operatorname{ars}^{66}$. Boskie stworzenie, posługując się analogią do ars humana, określa ars divina ${ }^{67}$. Bóg jest artrifex, fabricator ${ }^{68}$, a stworzenie pełne sprzecznych z sobą rzeczy pulcherrimum carmen ${ }^{69}$. Przeciwieństwa rzeczy ze sobą niezgodnych ułatwiają duchowe zrozumienie $\operatorname{ars}^{70}$.

Biskup Hippony podkreśla z niczym niezrównaną ars divina ${ }^{71}$, utożsamiając ją ze Stwórcą-Logosem Janowej Ewangelii ${ }^{72}$. Zachęca też do zaprzestania bycia dzieckiem w myśleniu, ale w miarę sił należy starać się wniknąć umysłem w wielkość boskiej sztuki.

Jedność, którą umysł podziwia i której sam jest obrazem, znaleźć można tylko w Bogu i dlatego Bóg jest największym artystą dającym natchnienie wszystkim sztukom. W Bogu jest niezmienna prawda ,słusznie uważana za zasadę wszelkiej umiejętności i sztukę wszechpotężnego Mistrza" (lex omnium artium recte dicitur et ars omnipotentis artificis $)^{73}$. Bóg stworzył piękno zniko-

${ }^{63}$ Por. De musica VI 14, 45, NBA 3/2, 688-691, Turkowska, s. 61; De Trinitate XII 13-16, NBA 4, 450-457, POK 25, 337-340; Confessiones X 54 -58, NBA 1, 346-353; Kubiak, s. 258-261.

${ }^{64}$ Por. De doctrina christiana II 23, 35 - 24, 37, Patres Ecclesiae, vol. 1, s. 86-91; De civitate Dei IV 34, NBA 5/1, 312-315.

${ }^{65}$ Por. tamże II 30-36; II 46, Patres Ecclesiae, vol. 1, s. 82-89; 96-99.

66 Por. Cicero, De natura deorum II 57.

67 Por. De Genesi ad litteram contra manichaeos I 13, 25; NBA 9/2, 38; De musica IV 5, 6, NBA 3/2, 536: ,veritas vocatur ars Dei supremi”; De diversis quaestionibus octoginta tribus quaestio 59 , NBA 6/2, 128: ,itaque respondens ait: amen dico vobis quod nescio vos, ex illa scilicet regula, qua non habet ars Dei, hoc est sapientia Dei, ut intrent in gaudium eius qui non coram Deo, sed ut placerent hominibus visi sunt aliquid secundum praecepta eius operari; atque ita concludit: vigilate ergo, quia nescitis diem neque horam, non modo illius ultimi temporis, quo venturus est sponsus. sed suae quisque dormitionis diem et horam nescit"; Enarrationes in Ps. 141, 15, NBA 38, 610-613.

${ }^{68}$ Por. Enarrationes in Ps. 141, 15, NBA 38, 612; De Genesi contra manichaeos I 2, 3, NBA 9/1, 62: „Quomodo enim erat tempus quod Deus non fecerat, cum omnium temporum ipse sit fabricator?".

69 Por. De civitate Dei XI 18, NBA 5/2, 98; zob. też Epistolae: 138, 5; 166, 13.

70 Por. De civitate Dei XI 18, NBA 5/2, 98-101.

71 Por. De civitate Dei XII 24-25, NBA 5/2, 206-211; De Genesi ad litteram contra manichaeos I 18, 36 i IV 8, 15, NBA 9/2, 50 i 174-177.

${ }^{72}$ Por. De civitate Dei $11,17,21$, NBA 5/2, 102-107.

73 De vera religione 31, 57, NBA 6/1, 90, Ptaszyński, s. 120. 
mych ciał $^{74}$, nieograniczone piękno duszy ludzkiej zdolnej do rozwoju ${ }^{75}$, trwałe i promienne piękno świata ${ }^{76}$. Nasz umysł dostrzega te wspaniałe piękności, ale jest zbyt słaby, by uchwycić ich pełnię ${ }^{77}$.

Człowiek jest tylko jedną sylabą boskiego poematu jedną nutą w hymnie, który śpiewa cały wszechświat. W odróżnieniu jednak od innych stworzeń, które urzeczywistniają piękno nie wiedząc o tym, człowiek myśli, czuje, żyje, zna sylabę, którą pisze i nutę, którą śpiewa i wie, że będą one tym piękniejsze im lepiej będą odtwarzały harmonię Boga. Święty Augustyn napisał wiele pięknych stron o tej wewnętrznej muzyce duszy, tym bardziej czystej i melodyjnej, im silniejszym jest echem wiecznych pieśni ${ }^{78}$. W tej muzyce duszy widzi koncert czterech cnót: roztropności, męstwa, sprawiedliwości i umiarkowania, rozszerzonych przez miłość i ubogaconych przez laskę ${ }^{79}$. Ten koncert boski, który sprawia, że dusza stając się bardzo piękna, a życie nader harmonijne, czyni arcydzieło sztuki.

Arcydzieła człowieka są piękne w miarę, jak odbijają piękno Boga. Malarz odtwarza przez rysunek i barwę jakiś przedmiot materialny lub postać ludzką. Odtworzenie to będzie tym doskonalsze, im bardziej z bliska naśladuje Stwórcę. Historyk usiłuje drogą analizy dokumentów ożywić przeszłość. Może mu się to udać o tyle, o ile kierując się tymi wydarzeniami, będzie stosował się do dłoni Opatrzności ${ }^{80}$. Poeta chce wyrazić w pięknych słowach rzeczywistość, która go dotyka oraz uczucia, które go poruszają. Piękno jego wierszy będzie tym większe, im wyżej będzie podnosił swój umysł i serce, a wspaniałość osiągnie wtedy, kiedy pogrąży się w modlitwie i adoracji ${ }^{81}$. Filozof usiłuje przebić w głębokim rozważaniu zasłony swej duszy i tajemnicę przeznaczenia. Jego dzieło piękne samo w sobie, stanie się wspaniałe z chwilą, gdy spotka Boga i pozna niebiańskie radości ekstazy i kontemplacji.

We wszystkich swych postaciach sztuka ma w sobie coś boskiego. Jej potęga twórcza pochodzi od Tego, który wszystko stworzył, jej prawa są wyrazem mądrości przedwiecznej, jej radości, których zawsze dostarcza; przynajmniej te najgłębsze i najbardziej żywe, mają w sobie coś religijnego. Biskup Hippony wyznaje:

„Lecz ja, Boże mój, chlubo moja, także za te rzeczy głoszę Tobie hymn pochwalny i składam dziękczynienie Temu, który mnie uświęca. Piękno bowiem, które przez

74 Por. tamże 21, 41, NBA 6/1, 68 i 70.

75 Por. De musica VI 13, 40, NBA 3/2, 684.

76 Por. tamże VI 11, 29, NBA 3/2, 668.

77 Por. tamże VI 11, 30, NBA 3/2, 670.

78 Por. De musica VI 17, 58, NBA 3/2, 704.

79 Por. tamże VI 16, 51 - 17, 57, NBA 3/2, 696-705.

${ }^{80}$ Por. A. Eckmann, Historia w świetle pism św. Augustyna, w: Studia nad kulturą antyczną, red. J. Roztropowicz, Opole 1997, 113-120.

81 Por. tenże, Moc poezji w ujęciu św. Augustyna, VoxP 8 (1988) z. 15, 811-816. 
dusze artystów spływa ku ich rękom, pochodzi od owej piękności, która ponad duszami jest i ku której dniem i nocą wzdycha dusza moja" ${ }^{82}$.

Nie można lepiej wyjaśnić roli Boga w arcydziełach człowieka i dlatego mimo niedoskonałości i słabości sztuka jest nieśmiertelna. To określenie wydaje się najlepszym wnioskiem, jaki możemy wyprowadzić z pism św. Augustyna na temat sztuki. Augustyńska koncepcja sztuki w swej głębi ma pochodzenie platońskie. Augustyn poucza, że piękno poematu, mowy koncertu, pochodzi z proporcji, harmonii, symetrii i jedności wszystkich jego składników. Ale też wskazuje - i to jest ideą chrześcijańską - że to piękno ludzkie jest odbiciem piękna Bożego i że artysta może je stworzyć i uczynić nieśmiertelnym, udzielając mu tajemniczego tchnienia Stwórcy. Tak pojęta sztuka ma w sobie coś religijnego, wprowadza w czyn zasady wieczne, graniczy z bóstwem.

Kultura św. Augustyna była tak bogata, głęboka i subtelna, że doprowadziła go do odnalezienia Boga na wszystkich drogach jego myśli, także w jego koncepcji sztuki. Wierny swej nauce ukląkł przed Bogiem i z zachwytem słuchał Jego nauki.

\section{QUAE SANCTUS AUGUSTINUS DE ARTE TRADIDERIT}

\section{(Argumentum)}

Disputatiuncula haec ex exordio, tribus capitibus cogruentibus cum materia operum sancti Augustini et epilogo composita est. Primum de pulchro artis in genere, deinde de arte humana, postremo de arte divina narrat. Sanctus Augustinus habebat aures et oculi qui facillime laeduntur. Technicam animalium ab arte humana discrevit. Ars humana a Deo creata est. Qui humanis ingeniis, quae creavit, etiam scientias artium variarum ad adiuvandam vitam naturamque concessit. Episcopus Hipponensis Deum artificem omnipotentem nominat et universitatem ab eo creatam artem divinam. Dei opus aliud non est ac eius arte. Sapientia Dei ars Dei est, ars Dei supremi veritas vocatur. In Deo Trino lex omnium artium et ars omnipotentis artificis est. Nec auctor est excellentior Deo, nec ars efficacior Dei Verbo. Deus operatur aeternis atque incommutabilibus et stabilibus rationibus coaeterni sibi Verbi sui et amore coaeterni Sancti Spiritus sui. Doctor Ecclesiae ad artem divinam cognoscendam exhortatur. Ipse Deo dicit hymnum et sacrificat laudem sacrificatori suo, quoniam pulchra traiecta per animas in manus artificiosas ab illo Pulchro veniunt, quod super animas est. 